\title{
Calcium oxalate crystal deposition in the kidney: identification, causes and consequences
}

\author{
R. Geraghty ${ }^{1} \cdot$ K. Wood ${ }^{2} \cdot$ J. A. Sayer ${ }^{1,3,4}$
}

Received: 23 June 2020 / Accepted: 17 July 2020 / Published online: 27 July 2020

(c) The Author(s) 2020

\begin{abstract}
Calcium oxalate $(\mathrm{CaOx})$ crystal deposition within the tubules is often a perplexing finding on renal biopsy of both native and transplanted kidneys. Understanding the underlying causes may help diagnosis and future management. The most frequent cause of $\mathrm{CaOx}$ crystal deposition within the kidney is hyperoxaluria. When this is seen in native kidney biopsy, primary hyperoxaluria must be considered and investigated further with biochemical and genetic tests. Secondary hyperoxaluria, for example due to enteric hyperoxaluria following bariatric surgery, ingested ethylene glycol or vitamin C overdose may also cause $\mathrm{CaOx}$ deposition in native kidneys. $\mathrm{CaOx}$ deposition is a frequent finding in renal transplant biopsy, often as a consequence of acute tubular necrosis and is associated with poorer long-term graft outcomes. CaOx crystal deposition in the renal transplant may also be secondary to any of the causes associated with this phenotype in the native kidney. The pathophysiology underlying $\mathrm{CaOx}$ deposition is complex but this histological phenotype may indicate serious underlying pathology and should always warrant further investigation.
\end{abstract}

Keywords Calcium oxalate $\cdot$ Oxalosis $\cdot$ Primary hyperoxaluria $\cdot$ Enteric hyperoxaluria

\section{Introduction}

Calcium oxalate $(\mathrm{CaOx})$ crystal deposition within the nephron [1-3], tubular cells [4] or interstitium [5] are sometimes found by the histopathologist examining a renal biopsy. $\mathrm{CaOx}$, along with calcium phosphate $(\mathrm{CaP})$ deposition may lead to nephrocalcinosis [6,7], although in practice $\mathrm{CaOx}$ crystal deposition is often referred to as renal oxalosis or oxalate nephropathy. Bagnasco et al. examined biopsies of both native and transplanted kidneys over the course of 6 years [6]. Overall, $1 \%$ of native kidney biopsies and $4 \%$

\section{J. A. Sayer}

John.sayer@newcastle.ac.uk

1 Renal Services, The Newcastle Hospitals NHS Foundation Trust, Newcastle upon Tyne NE7 7DN, UK

2 Histopathology Department, The Newcastle Hospitals NHS Foundation Trust, Newcastle upon Tyne NE1 4LP, UK

3 Translational and Clinical Research Institute, Faculty of Medical Sciences, International Centre for Life, Newcastle University, Central Parkway, Newcastle upon Tyne NE1 3BZ, UK

4 NIHR Newcastle Biomedical Research Centre, Newcastle upon Tyne, UK of transplanted kidney biopsies demonstrated $\mathrm{CaOx}$ crystal deposition.

The presence of $\mathrm{CaOx}$ crystal deposition within a renal biopsy may indicate serious underlying pathology and indicate an underlying diagnosis that may not have previously been considered $[7,8]$. Of particular relevance are the primary hyperoxalurias $(\mathrm{PH})$, which may cause end stage kidney disease and may recur following kidney transplantation. The diagnosis of $\mathrm{PH}$ has potentially life-changing effects with a broad range of treatment options, up to and including dual kidney and liver transplant $[9,10]$.

Crystalluria, although associated with hyperoxaluria [11], is an uncommon finding [12-14]. There are no descriptions of the association between $\mathrm{CaOx}$ crystalluria and renal oxalosis. Here we aim to explore the causes of $\mathrm{CaOx}$ crystal deposition within a renal biopsy and therefore the implications and future management for the patient. We will review the histological appearances, the substrates that are most likely to cause $\mathrm{CaOx}$ crystal deposition and the pathophysiology associated with $\mathrm{CaOx}$ crystal deposition. 


\section{Histology of calcium oxalate deposition}

Oxalate crystals precipitate in renal tubules causing tubular injury and in the longer term, interstitial fibrosis and tubular atrophy. They have a clear appearance on light microscopy [15] (Fig. 1a) but are much more easily seen when viewed under polarised light where they show bright birefringence (Fig. 1b). Particularly abundant crystals are typically associated with $\mathrm{PH}$ or ethylene glycol ingestion. Lesser degrees of deposition can be seen in a wide variety of conditions, which are discussed below. The main pathological differential diagnosis is 2,8 dihydroxyadenine crystalline nephropathy other cause of polarisable crystals seen in the kidney by the histopathologist. These patients, with biallelic mutations in APRT, have adenine phosphoribosyltransferase deficiency and often develop recurrent nephrolithiasis. Diagnosis can
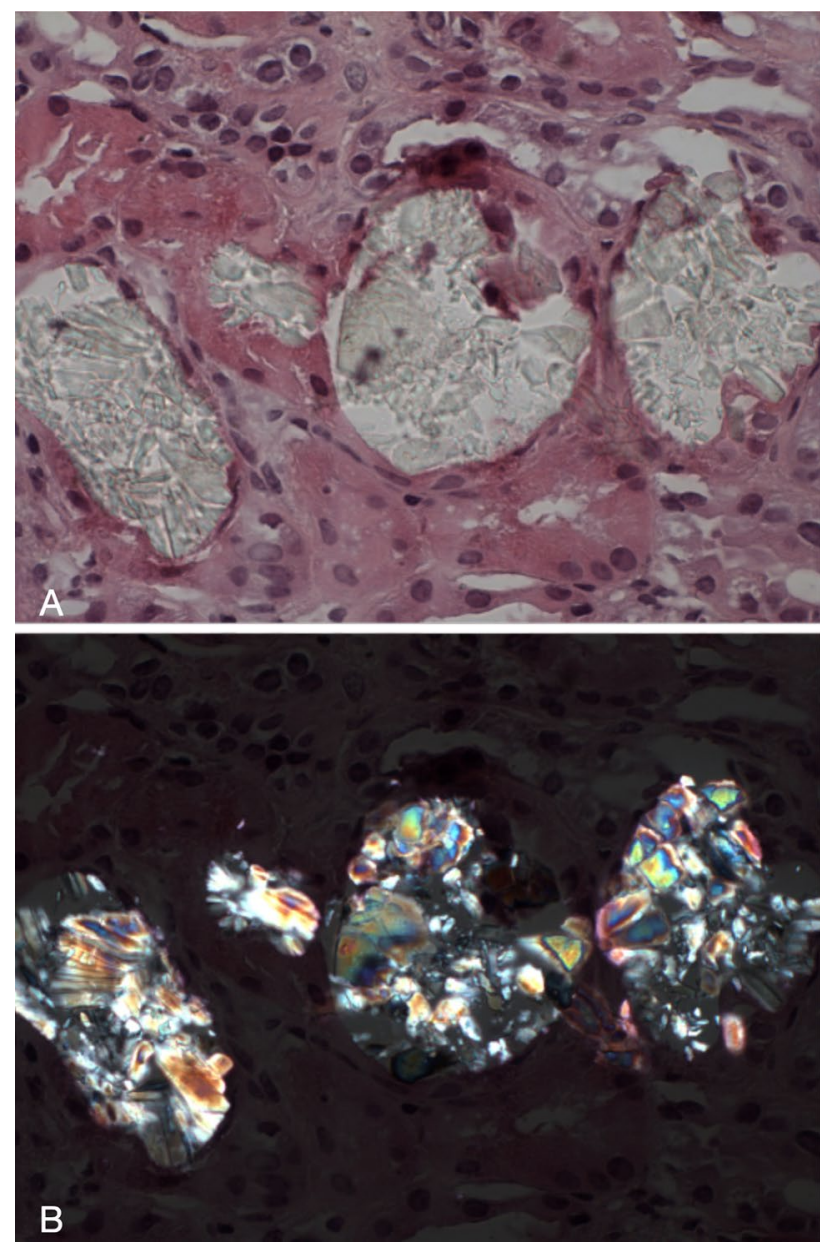

Fig. $1 \mathbf{a}=$ Oxalate nephropathy. A transplant kidney biopsy showing calcium oxalate crystals in dilated tubules. The crystals are clear with a refractile quality on routine microscopy (haematoxylin and eosin $\times 400)$. $\mathbf{b}=$ Oxalate nephropathy. The same calcium oxalate crystals exhibit bright birefringence when viewed under polarised light (polarised haematoxylin and eosin $\times 400$ ) be challenging but the crystals can be distinguished from calcium oxalate crystals by their brown colour on haematoxylin and eosin staining [16].

\section{Calcium and oxalate: a tale of two substrates}

Hypercalciuria and hyperoxaluria are both known to cause crystal deposition within the kidney [17]. In patients with hypercalciuria, the primary crystal deposited is $\mathrm{CaP}$ [2], this nidus may form the focus of aggregation for either $\mathrm{CaP}$ or $\mathrm{CaOx}$ [18] This variable aggregation has been demonstrated in vitro [19], in rat models [17, 20], and observed in humans [2]. However, in patients with hyperoxaluria the predominant crystal type is $\mathrm{CaOx}$ [21]; this has again been demonstrated in a rat model [17], in vitro [4, 5, 22] and in humans [2].

Crystal type and the components of subsequent aggregation are dependent upon specific locations along the nephron and degrees of supersaturation. In the urinary space, it seems that a $\mathrm{CaP}$ nidus initiates subsequent $\mathrm{CaOx}$ aggregation in the in vitro model [19], as in nephrolithiasis.

In the kidney, the type of crystal deposition appears to be different dependent on the location along the nephron. $\mathrm{CaP}$ crystals have been observed in the interstitium surrounding the ascending thin limb of the loop of Henle [2], in stoneforming patients with hypercalciuria. $\mathrm{CaOx}$ crystal deposition is typically seen more distally, having been observed within the collecting duct and the interstitium surrounding it $[1,14]$.

The situation therefore appears that in hypercalciuria, $\mathrm{CaP}$ crystals are deposited within and around the nephron, especially near the loop of Henle. By contrast, in hyperoxaluria, $\mathrm{CaOx}$ crystal deposition is found within collecting duct nephron segments. To test this hypothesis, Khan and Glenton examined hypercalciuric mice with increasing levels of oxaluria [20]. They demonstrated that in the genetic hypercalciuric stone-forming (GHS) rat model before dietary manipulation, only $\mathrm{CaP}$ crystals were formed. However, as the oxalate precursor hydroxyproline was added to their diet, $\mathrm{CaOx}$ crystals were observed. As hydroxyproline concentrations increased, inducing a hyperoxaluria, the crystal type switched to become entirely $\mathrm{CaOx}$. This suggests that intrarenal $\mathrm{CaOx}$ crystal formation is dependent upon hyperoxaluria rather than hypercalciuria.

The mechanism of $\mathrm{CaOx}$ deposition within the kidney is subject to several factors. These include supersaturation and precipitation, crystal aggregation and deposition within the tubule/epithelium/interstitium. Several studies have demonstrated that hyperoxaluria induces intratubular precipitation of $\mathrm{CaOx}$ crystals located in the collecting duct $[1,23]$. There are two potential mechanisms by which crystal passage through the tubule is inhibited (crystal retention). They have either aggregated and become too large [24, 
25], or they have adhered to the epithelium [26]. Following either of these mechanisms, $\mathrm{CaOx}$ crystals then migrate into the epithelium [27] and interstitium [5]. The process behind this migration is unclear. However, crystal containing macrophages have been observed in both animal [28, 29] and human [30] epithelium/interstitium. Therefore active removal by macrophages is a possible mechanism for this observation, although this has yet to be demonstrated.

\section{Pathologies associated with calcium oxalate crystal deposition}

$\mathrm{CaOx}$ crystal deposition may be noted in both native and transplanted kidneys, as a consequence of hyperoxaluria. Oxalate has both endogenous and exogenous sources $[31,32]$ and both are equally able to induce hyperoxaluria (defined as $>40-45 \mathrm{mg}$ per $24 \mathrm{~h}$ or $>0.45-0.5 \mathrm{mmol}$ per $24 \mathrm{~h}$ ). Tubular $\mathrm{CaOx}$ deposition leading to acute or chronic tubular injury, interstitial fibrosis and progressive renal insufficiency is termed oxalate nephropathy or renal oxalosis.

Both native and transplanted kidneys are susceptible to hyperoxaluria and subsequent oxalate nephropathy and the causes for hyperoxaluria and crystal deposition differ (Table 1).

On light microscopy 2,8-hydroxyadenine crystals may mimic $\mathrm{CaOx}$ crystals under polarized light, because of their high birefringence [15]. However, the finding of 2,8-hydroxyadenine crystals mimicking $\mathrm{CaOx}$ crystals can lead to a rare, often missed and important genetic diagnosis being made. Likewise, genuine $\mathrm{CaOx}$ deposition can lead to other important diagnoses being made and should never be ignored.
Diabetes mellitus is a common cause of nephropathy and it is unclear whether it is associated with renal oxalosis. Diabetics have demonstrably higher urinary oxalate concentrations than healthy patients [33]. They have also been observed to develop oxalate nephropathy in several case reports [34, 35]. However, in these case reports, the patients had independent risk factors for renal oxalosis including Roux-en-Y bypass and increased dietary oxalate. Moreover, $\mathrm{CaOx}$ crystals are not among the number of histological features of diabetic nephropathy $[36,37]$. A large study of cadaveric renal biopsies examined risk factors associated with renal oxalosis [38] Diabetes mellitus was shown not to be associated with renal oxalosis. Therefore, if $\mathrm{CaOx}$ crystals are seen on renal biopsy of a patient with diabetes, the likely driving factor is hyperoxaluria. The type and cause of hyperoxaluria should therefore be investigated as this may lead to important changes in patient management.

\section{Primary hyperoxaluria}

Primary hyperoxaluria is a rare autosomal recessive disorder associated with renal $\mathrm{CaOx}$ crystal deposition. Oxalate is an end metabolite for glyoxylate and the three types of primary hyperoxalurias (PH1-3) affect enzymes of glyoxylate metabolism. The enzymes implicated are: alanine glyoxylate aminotransferase (PH1) [39], glycolate reductase/hydroxypyruvate reductase (PH2) [40] and 4-hydroxy-2-ketoglutarate aldolase (PH3) [41, 42]. These disorders tend to present in childhood to early adolescence with severe recurrent nephrolithiasis, although given some may be asymptomatic (especially PH3), they may not present until the development of advanced renal failure. PH may also present in late adult life with calcium oxalate stone formation or insidious chronic kidney disease.

Table 1 Causes of Calcium Oxalate crystal deposition within the native and transplanted kidney

\begin{tabular}{ll}
\hline Calcium oxalate crystal deposition & \\
\hline Native kidney & $\begin{array}{c}\text { Transplanted kidney } \\
\text { Causes as per native kidney } \\
\text { Primary hyperoxaluria - types 1-3 }\end{array}$ \\
$\begin{array}{c}\text { Transient hyperoxaluria due to sudden increase in GFR and } \\
\text { previous systemic oxalosis secondary to end stage kidney } \\
\text { disease }\end{array}$ \\
$\begin{array}{l}\text { Enteric hyperoxaluria (fat malabsorption) } \\
\text { High oxalate diet }\end{array}$ \\
$\begin{array}{l}\text { Ethylene glycol intoxication } \\
\text { Thiamine/Pyridoxine deficiency }\end{array}$ \\
Vitamin C overdose (precursor of oxalic acid) \\
Orlistat use \\
Alterations in intestinal flora \\
Genetic variations of oxalate transporters \\
Acute tubular necrosis
\end{tabular}


The majority of cases are PH1, which have the most severe disease phenotypes. PH1 and PH2 both cause progressive nephrocalcinosis, nephrolithiasis and renal damage resulting in early end stage renal failure [13, 26-28]. With the progressive decline in renal function comes rising plasma oxalate levels. At a glomerular filtration rate $<45 \mathrm{ml} /$ $\min / 1.73 \mathrm{~m}^{2}$ plasma oxalate concentrations exceed the supersaturation threshold leading to systemic deposition of $\mathrm{CaOx}$ (systemic oxalosis) [43]. This leads to early death if left untreated [44].

It is unclear if patients with $\mathrm{PH} 3$ have the same natural history as $\mathrm{PH} 1 / 2$ given its rarity and recent description. Recent data has shown children with PH3 show a decline in renal function [45]. However, there remains a lack of longterm follow-up data to allow for an accurate description of its clinical course. It is possible that all types of $\mathrm{PH}$ may present with unexplained chronic kidney disease and $\mathrm{CaOx}$ crystal deposition on renal biopsy.

\section{Secondary hyperoxalurias}

Secondary hyperoxaluria may be due to a number of different causes. The passage of oxalate through the body helps illustrate why differing mechanisms cause hyperoxaluria. There is a large oxalate content in certain foods [46], which is both metabolized by gut commensals (Oxalobacter formigenes) [47] and absorbed into the enterohepatic circulation $[48,49]$. Absorbed oxalate is then filtered and excreted in the kidney $[48,49]$ along with oxalate produced as an end-point of glyoxylate metabolism.

At each of these points, excess oxalate may occur. Case reports describing high intakes of oxalate containing foods [46] or vitamin C [50] (which is catabolized into oxalate) are associated with hyperoxaluria. Deficiencies, dietary or otherwise, in thiamine or pyridoxine [51-54], deliberate ingestion of orlistat [55] or ethylene glycol [56, 57] may also lead to hyperoxaluria. High doses of vitamin C [50], some foods [58-61], excessive dieting [62] and ethylene glycol [56] have been demonstrated to induce acute oxalate nephropathy.

The gut commensal Oxalobacter formigenes, catabolizes oxalate thus diminishing gut absorption $[63,64]$. There has been an attempt to exploit this phenomenon for $\mathrm{PH}$, which showed initial promise, but unfortunately failed in phase II/ III trials [65]. Although touted as a treatment, there have not been further studies of its effectiveness to treat secondary hyperoxaluria.

Several case reports have associated hyperoxaluria with bariatric surgery $[66,67]$ as well as chronic pancreatitis $[68,69]$, with both conditions associated with acute oxalate nephropathy $[66,68]$. Increased oxalate absorption is a function of fat malabsorption (enteric hyperoxaluria). In the normal state, oxalate is bound to calcium within the gut. Fat malabsorption leads to free fatty acids binding to calcium, leaving the oxalate in its absorbable, ionised state [49].

Mice and humans with genetic variations of gut oxalate transporters have also been demonstrated to have increased urinary oxalate [70] Deletion of Slc26a6 in mice [71, 72] along with variants V185M in the SLC26A6 transporter in humans [73] have both been associated with hyperoxaluria. None of these studies performed renal biopsies and therefore further study is required to see if these are risk factors for oxalate nephropathy and $\mathrm{CaOx}$ deposition.

\section{Transplanted kidneys}

Around $4 \%$ of transplanted kidneys will display $\mathrm{CaOx}$ crystals on biopsy [6]. Crystals can be found early or late, distributed throughout the kidney or only in focal segments.

In the initial post-operative period it is thought that, due to the poor renal function indicating the need for transplant, there is systemic oxalosis. With the improvement in renal function attained by transplantation there is rapid excretion of the excess oxalate. This leads to a transient hyperoxaluria with a small proportion developing subsequent renal precipitation of $\mathrm{CaOx}$ [74]. There is debate as to whether or not this initial transient hyperoxaluria is pathological, and long-term outcomes of this have not been proven.

There is more evidence for the implications of $\mathrm{CaOx}$ crystals on renal biopsy, albeit conflicting. In the short term, the presence of $\mathrm{CaOx}$ crystals on graft biopsy up to 3 months after transplantation seems to be associated with poorer longer term graft survival [75]. Although a later study demonstrated that, although graft function at 1 year was significantly poorer in those with $\mathrm{CaOx}$ deposition, there was no statistically significant difference in renal function at 2 years [6]. In this second study however, there was an overall drop in both control and crystal graft function in the second year compared to the first. It is likely that $\mathrm{CaOx}$ crystals are a negative prognostic indicator for long-term graft survival in the initial period following transplantation. These patients should be followed-up closely.

Delayed graft function and acute tubular necrosis (ATN) or acute cell-mediated rejection is associated with focal $\mathrm{CaOx}$ deposition [76, 77]. The long-term impact of these acute events is unclear. The majority of transplanted kidneys demonstrated normal function at follow-up [76]. However, these observations were underpowered, lacked follow-up biopsies, and biochemical data for clinical correlation. The authors postulated this observation was due to high oxalate excretion using the mechanism previously described. However, inferring this mechanism from the data is difficult due to the lack of clinical context and small numbers of patients.

In the longer term, $\mathrm{CaOx}$ crystals are seen on biopsy of those with chronic allograft nephropathy [76]. In the two patients studied, $\mathrm{CaOx}$ crystal deposition was widespread 
in keeping with chronic renal failure (mechanism discussed below). An earlier study by Memeo et al. of forty allograft nephrectomies showed $87 \%$ had widespread $\mathrm{CaOx}$ crystals [78]. Again, given the low numbers it is difficult to draw conclusions from these case reports, but they suggest $\mathrm{CaOx}$ crystals, identified at any point in time from biopsy, are associated with long-term graft failure.

Transplanted kidneys can also be affected by any of the primary or secondary hyperoxalurias. Failure to diagnose $\mathrm{PH}$ prior to transplantation may result in early graft failure [79, 80]. Likewise for secondary hyperoxalurias, failure to recognise may lead to acute kidney injury [81] or even graft failure. There have been graft failure case reports for enteric hyperoxaluria [82, 83] and excessive vitamin C intake [84].

\section{Pathophysiology of renal damage associated with crystal deposition}

Severe hyperoxaluria has been demonstrated to be clinically associated with acute or chronic renal failure, although it is unclear which is causative of the other. It is also unclear whether mild to moderate hyperoxaluria, such as that seen in $\mathrm{PH} 3$, is associated with renal damage, despite evidence of $\mathrm{CaOx}$ crystal deposition in both conditions.

There is a large body of evidence from rat and in vitro models, and human observation that $\mathrm{CaOx}$ crystal deposition is associated with renal epithelial damage [4, 5, 85-89]. Differing structures of $\mathrm{CaOx}$ crystals can damage renal epithelial cells inducing apoptosis [22]. This body of evidence suggests that epithelial injury and progressive inflammation is caused by $\mathrm{CaOx}$ crystals, rather than $\mathrm{CaOx}$ crystals forming secondary to renal damage. This explains the findings in $\mathrm{PH}$ and severe secondary hyperoxaluria.

The observation that $\mathrm{CaOx}$ crystals are only found in focal segments of acute tubular necrosis in transplanted kidneys $[76,77]$ however, does not fit with the widespread renal damage and $\mathrm{CaOx}$ crystals of hyperoxaluria. It implies that $\mathrm{CaOx}$ crystal deposition seen in this situation is secondary to focal epithelial damage [4], rather than crystal precipitation and subsequent epithelial damage.

The pathophysiology of renal oxalosis secondary to severe hyperoxaluria has been described. However, the mechanism of focal $\mathrm{CaOx}$ crystal deposition in acute tubular necrosis remains unclear. $\mathrm{CaOx}$ crystals on renal biopsy should always prompt investigation for serious underlying conditions in both the native and transplanted kidney (Table 1), that could lead to progressive renal failure.

\section{Conclusion}

$\mathrm{CaOx}$ crystals identified histologically on renal biopsy are indicative of a potential underlying pathology. This finding warrants further investigation to determine the cause, the most serious of which is PH. Much of the clinical literature describing conditions associated with $\mathrm{CaOx}$ crystal deposition are case reports. In the long-term there appears to be a potential association between $\mathrm{CaOx}$ deposition and increased risk of chronic kidney disease. Larger studies are needed to examine this association in more depth.

Acknowledgements RG is supported by the National Institute for Health Research. JAS is supported by the Northern Counties Kidney Research Fund and Kidney Research UK.

\section{Compliance with Ethical Standards}

Conflicts of interest The authors have no conflicts of interest to declare.

Statement of human and animal rights All procedures performed in studies involving human participants were in accordance with the ethical standards of the institutional research committee and with the 1964 Helsinki declaration and its later amendments or comparable ethical standards.

Informed consent Informed written consent was obtained for use of patient biopsy images in this article.

Open Access This article is licensed under a Creative Commons Attribution 4.0 International License, which permits use, sharing, adaptation, distribution and reproduction in any medium or format, as long as you give appropriate credit to the original author(s) and the source, provide a link to the Creative Commons licence, and indicate if changes were made. The images or other third party material in this article are included in the article's Creative Commons licence, unless indicated otherwise in a credit line to the material. If material is not included in the article's Creative Commons licence and your intended use is not permitted by statutory regulation or exceeds the permitted use, you will need to obtain permission directly from the copyright holder. To view a copy of this licence, visit http://creativecommons.org/licenses/by/4.0/.

\section{References}

1. Kok DJ (1996) Crystallization and stone formation inside the nephron. Scan Microsc 10:471-484 (discussion 484-6)

2. Evan AP, Lingeman JE, Coe FL et al (2003) Randall's plaque of patients with nephrolithiasis begins in basement membranes of thin loops of Henle. J Clin Invest 111:607-616. https://doi. org/10.1172/JCI17038

3. Evan AP, Coe FL, Lingeman J et al (2018) Randall's plaque in stone formers originates in ascending thin limbs. Am J Physiol Renal Physiol 315:F1236-F1242. https://doi.org/10.1152/ajpre nal.00035.2018

4. Khan SR (1995) Calcium oxalate crystal interaction with renal tubular epithelium, mechanism of crystal adhesion and its 
impact on stone development. Urol Res 23:71-79. https://doi. org/10.1007/bf00307936

5. Water R, Noordermeer C, Kwast TH et al (1999) Calcium oxalate nephrolithiasis effect of renal crystal deposition on the cellular composition of the renal interstitium. Am J Kidney Dis 33:761-771. https://doi.org/10.1016/s0272-6386(99)70231-3

6. Bagnasco SM, Mohammed BS, Mani H et al (2009) Oxalate deposits in biopsies from native and transplanted kidneys, and impact on graft function. Nephrol Dial Transplant 24:13191325. https://doi.org/10.1093/ndt/gfn697

7. Sayer JA, Carr G, Simmons NL (2004) Nephrocalcinosis: molecular insights into calcium precipitation within the kidney. Clin Sci 106:549-561. https://doi.org/10.1042/CS20040048

8. Dickson FJ, Sayer JA (2020) Nephrocalcinosis: a review of monogenic causes and insights they provide into this heterogeneous condition. Int J Mol Sci 21:369. https://doi.org/10.3390/ ijms21010369

9. Watts RW, Calne RY, Rolles K et al (1987) Successful treatment of primary hyperoxaluria type I by combined hepatic and renal transplantation. Lancet 2:474-475. https://doi.org/10.1016/ s0140-6736(87)91791-0

10. Kotb MA, Hamza AF, Abd El Kader H et al (2019) Combined liver-kidney transplantation for primary hyperoxaluria type I in children: single center experience. Pediatr Transplant 23:e13313. https://doi.org/10.1111/petr.13313

11. Daudon M, Jungers P, Lacour B (2004) Intérêt clinique de l'étude de la cristallurie. Ann Biol Clin 62:379-393

12. Winkens RA, Wielders JP, Degenaar CP, van Hoof JP (1988) Calcium oxalate crystalluria, a curiosity or a diagnostical aid? J Clin Chem Clin Biochem 26:653-654

13. Robert M, Boularan AM, Delbos O et al (1998) Study of calcium oxalate crystalluria on renal and vesical urines in stone formers and normal subjects. Urol Int 60:41-46. https://doi. org/10.1159/000030201

14. Elliot JS, Rabinowitz IN (1980) Calcium oxalate crystalluria: crystal size in urine. JURO 123:324-327. https://doi.org/10.1016/ s0022-5347(17)55918-2

15. Herlitz LC, D’Agati VD, Markowitz GS (2012) Crystalline nephropathies. Arch Pathol Lab Med 136:713-720. https://doi. org/10.5858/arpa.2011-0565-RA

16. Bagai S, Khullar D, Bansal B (2019) Rare crystalline nephropathy leading to acute graft dysfunction: a case report. BMC Nephrol 20:428-433. https://doi.org/10.1186/s12882-019-1616-3

17. Evan AP, Bledsoe SB, Smith SB, Bushinsky DA (2004) Calcium oxalate crystal localization and osteopontin immunostaining in genetic hypercalciuric stone-forming rats. Kidney Int 65:154-161. https://doi.org/10.1111/j.1523-1755.2004.00396.x

18. Sayer JA, Simmons NL (2002) Urinary stone formation: Dent's disease moves understanding forward. Exp Nephrol 10:176-181. https://doi.org/10.1159/000058344

19. Xie B, Halter TJ, Borah BM, Nancollas GH (2015) Aggregation of calcium phosphate and oxalate phases in the formation of renal stones. Cryst Growth Des 15:204-211. https://doi.org/10.1021/ $\operatorname{cg} 501209 \mathrm{~h}$

20. Khan SR, Glenton PA (2008) Calcium oxalate crystal deposition in kidneys of hypercalciuric mice with disrupted type IIa sodiumphosphate cotransporter. Am J Physiol Renal Physiol 294:F1109_ F1115. https://doi.org/10.1152/ajprenal.00620.2007

21. Hoppe B (2012) An update on primary hyperoxaluria. Nat Rev Nephrol 8:467-475. https://doi.org/10.1038/nrneph.2012.113

22. Sun X-Y, Ouyang J-M, Yu K (2017) Shape-dependent cellular toxicity on renal epithelial cells and stone risk of calcium oxalate dihydrate crystals. Sci Rep 7:7250-7313. https://doi.org/10.1038/ s41598-017-07598-7

23. Kok DJ (1997) Intratubular crystallization events. World J Urol 15:219-228. https://doi.org/10.1007/bf01367659
24. Kok DJ, Khan SR (1994) Calcium oxalate nephrolithiasis, a free or fixed particle disease. Kidney Int 46:847-854. https://doi. org/10.1038/ki.1994.341

25. Robertson WG (2015) Potential role of fluctuations in the composition of renal tubular fluid through the nephron in the initiation of Randall's plugs and calcium oxalate crystalluria in a computer model of renal function. Urolithiasis 43(1):93-107. https://doi. org/10.1007/s00240-014-0737-1

26. Verkoelen CF, Van Der Boom BG, Kok DJ et al (1999) Attachment sites for particles in the urinary tract. J Am Soc Nephrol 10(14):S430-S435

27. Ebisuno S, Kohjimoto Y, Tamura M et al (1997) Histological observations of the adhesion and endocytosis of calcium oxalate crystals in MDCK cells and in rat and human kidney. Urol Int 58:227-231. https://doi.org/10.1159/000282989

28. Water R, Noordermeer C, Houtsmuller AB et al (2000) Role of macrophages in nephrolithiasis in rats an analysis of the renal interstitium. Am J Kidney Dis 36:615-625. https://doi. org/10.1053/ajkd.2000.16203

29. Thurgood LA, Sørensen ES, Ryall RL (2012) The effect of intracrystalline and surface-bound osteopontin on the degradation and dissolution of calcium oxalate dihydrate crystals in MDCKII cells. Urol Res 40:1-15. https://doi.org/10.1007/s00240-011-0423-5

30. Kusmartsev S, Dominguez-Gutierrez PR, Canales BK et al (2016) Calcium oxalate stone fragment and crystal phagocytosis by human macrophages. J Urol 195:1143-1151. https://doi. org/10.1016/j.juro.2015.11.048

31. Holmes RP, Goodman HO, Assimos DG (2001) Contribution of dietary oxalate to urinary oxalate excretion. Kidney Int 59:270 276. https://doi.org/10.1046/j.1523-1755.2001.00488.x

32. Holmes RP, Ambrosius WT, Assimos DG (2005) Dietary oxalate loads and renal oxalate handling. JURO 174:943-947. https ://doi.org/10.1097/01.ju.0000169476.85935.e2

33. Eisner BH, Porten SP, Bechis SK, Stoller ML (2010) Urolithiasis/endourology diabetic kidney stone formers excrete more oxalate and have lower urine ph than nondiabetic stone formers. JURO 183:2244-2248. https://doi.org/10.1016/j. juro.2010.02.007

34. Moutzouris D-A, Skaneli G, Margellos V et al (2011) Oxalate nephropathy in a diabetic patient after gastric by-pass. Clin Nephrol 75(1):16-19

35. Muji A, Moll S, Saudan P (2015) Oxalate nephropathy: a new entity of acute kidney injury in diabetic patients? Rev Med Suisse 11:493-496

36. Fioretto P, Mauer M (2007) Histopathology of diabetic nephropathy. Semin Nephrol 27:195-207. https://doi.org/10.1016/j.semne phrol.2007.01.012

37. Fioretto P, Barzon I, Mauer M (2014) Is diabetic nephropathy reversible? Diabetes Res Clin Pract 104:323-328. https://doi. org/10.1016/j.diabres.2014.01.017

38. Mori S, Beppu T (1983) Secondary renal oxalosis. A statistical analysis of its possible causes. Acta Pathol Jpn 33:661-669

39. Danpure CJ, Jennings PR (1986) Peroxisomal alanine:glyoxylate aminotransferase deficiency in primary hyperoxaluria type I. FEBS Lett 201:20-34. https://doi.org/10.1016/00145793(86)80563-4

40. Cramer SD, Ferree PM, Lin K et al (1999) The gene encoding hydroxypyruvate reductase (GRHPR) is mutated in patients with primary hyperoxaluria type II. Hum Mol Genet 8:2063-2069. https://doi.org/10.1093/hmg/8.11.2063

41. Williams EL, Bockenhauer D et al (2012) The enzyme 4-hydroxy2-oxoglutarate aldolase is deficient in primary hyperoxaluria type 3. Nephrol Dial Transplant 27:3191-3195. https://doi. org/10.1093/ndt/gfs039

42. Huang A, Burke J, Bunker RD et al (2019) Regulation of human 4-hydroxy-2-oxoglutarate aldolase by pyruvate and 
$\alpha$-ketoglutarate: implications for primary hyperoxaluria type-3. Biochem J 476:3369-3383. https://doi.org/10.1042/BCJ20190548

43. Leumann E, Hoppe B (2001) The primary hyperoxalurias. J Am Soc Nephrol 12:1986-1993

44. Milliner DS, Wilson DM, Smith LH (2001) Phenotypic expression of primary hyperoxaluria: comparative features of types I and II. Kidney Int 59:31-36. https://doi.org/10.104 6/j.1523-1755.2001.00462.x

45. Allard L, Cochat P, Leclerc A-L et al (2015) Renal function can be impaired in children with primary hyperoxaluria type 3 . Pediatr Nephrol 30:1807-1813. https://doi.org/10.1007/s0046 7-015-3090-x

46. Noonan SC, Savage GP (1999) Oxalate content of foods and its effect on humans. Asia Pac J Clin Nutr 8:64-74

47. Stewart CS, Duncan SH, Cave DR (2004) Oxalobacter formigenes and its role in oxalate metabolism in the human gut. FEMS Microbiol Lett 230:1-7. https://doi.org/10.1016/S0378-1097(03)00864 $-4$

48. Hatch M, Freel RW (2003) Renal and intestinal handling of oxalate following oxalate loading in rats. Am J Nephrol 23:18-26. https://doi.org/10.1159/000066300

49. Whittamore JM, Hatch M (2017) The role of intestinal oxalate transport in hyperoxaluria and the formation of kidney stones in animals and man. Urolithiasis 45:89-108. https://doi.org/10.1007/ s00240-016-0952-z

50. Wong K, Thomson C, Bailey RR et al (1994) Acute oxalate nephropathy after a massive intravenous dose of vitamin C. Aust N Z J Med 24:410-411. https://doi.org/10.1111/j.1445-5994.1994. tb01477.x

51. Tiselius HG, Almgård LE (1977) The diurnal urinary excretion of oxalate and the effect of pyridoxine and ascorbate on oxalate excretion. Eur Urol 3:41-46. https://doi.org/10.1159/000472053

52. Hannett B, Thomas DW, Chalmers AH et al (1977) Formation of oxalate in pyridoxine or thiamin deficient rats during intravenous xylitol infusions. J Nutr 107:458-465. https://doi.org/10.1093/ jn/107.3.458

53. Gill HS, Rose GA (1986) Mild metabolic hyperoxaluria and its response to pyridoxine. Urol Int 41:393-396. https://doi. org/10.1159/000281241

54. Svedruzić D, Jónsson S, Toyota CG et al (2005) The enzymes of oxalate metabolism: unexpected structures and mechanisms. Arch Biochem Biophys 433:176-192. https://doi.org/10.1016/j. abb.2004.08.032

55. Solomon LR, Nixon AC, Ogden L (2017) Nair B (2017) Orlistat-induced oxalate nephropathy: an under-recognised cause of chronic kidney disease. BMJ Case Rep 21:6-23. https://doi. org/10.1136/bcr-2016-218623

56. Ting SMS, Ching I, Nair H et al (2009) Early and late presentations of ethylene glycol poisoning. Am J Kidney Dis 53:10911097. https://doi.org/10.1053/j.ajkd.2008.12.019

57. Hanouneh M, Chen TK (2017) Calcium oxalate crystals in ethylene glycol toxicity. N Engl J Med 377:1467-1467. https://doi. org/10.1056/NEJMicm1704369

58. Syed F, Mena-Gutierrez A, Ghaffar U (2015) A case of icedtea nephropathy. N Engl J Med 372:1377-1378. https://doi. org/10.1056/NEJMc1414481

59. Getting JE, Gregoire JR, Phul A, Kasten MJ (2013) Oxalate nephropathy Due to "Juicing": case report and review. Am J Med 126:768-772. https://doi.org/10.1016/j.amjmed.2013.03.019

60. Lien Y-HH (2013) Juicing is not all juicy. Am J Med 126:755756. https://doi.org/10.1016/j.amjmed.2013.04.007

61. Makkapati S, D'Agati VD, Balsam L (2018) "Green smoothie cleanse" causing acute oxalate nephropathy. Am J Kidney Dis 71:281-286. https://doi.org/10.1053/j.ajkd.2017.08.002

62. Khneizer G, Al-Taee A, Mallick MS, Bastani B (2017) Chronic dietary oxalate nephropathy after intensive dietary weight loss regimen. J Nephropathol 6:126-129. https://doi.org/10.15171/ jnp.2017.21

63. Mittal RD, Kumar R (2004) Gut-inhabiting bacterium Oxalobacterformigenes: role in calcium oxalate urolithiasis. J Endourol 18:418-424. https://doi.org/10.1089/0892779041271706

64. Hatch M, Cornelius J, Allison M et al (2006) Oxalobacter sp. reduces urinary oxalate excretion by promoting enteric oxalate secretion. Kidney Int 69:691-698. https://doi.org/10.1038/ sj.ki.5000162

65. Milliner D, Hoppe B, Groothoff J (2018) A randomised Phase II/ III study to evaluate the efficacy and safety of orally administered Oxalobacter formigenes to treat primary hyperoxaluria. Urolithiasis 46:313-323. https://doi.org/10.1007/s00240-017-0998-6

66. Nasr SH, D’Agati VD, Said SM et al (2008) Oxalate nephropathy complicating Roux-en-Y Gastric Bypass: an underrecognized cause of irreversible renal failure. Clin J Am Soc Nephrol 3:16761683. https://doi.org/10.2215/CJN.02940608

67. Sinha MK, Collazo-Clavell ML, Rule A et al (2007) Hyperoxaluric nephrolithiasis is a complication of Roux-en-Y gastric bypass surgery. Kidney Int 72:100-107. https://doi.org/10.1038/ sj.ki.5002194

68. Cartery C, Faguer S, Karras A et al (2011) Oxalate nephropathy associated with chronic pancreatitis. Clin J Am Soc Nephrol 6:1895-1902. https://doi.org/10.2215/CJN.00010111

69. Demoulin N, Issa Z, Crott R et al (2017) Enteric hyperoxaluria in chronic pancreatitis. Medicine (Baltimore) 96:e6758. https://doi. org/10.1097/MD.0000000000006758

70. Sayer JA (2017) Progress in understanding the genetics of calcium-containing nephrolithiasis. J Am Soc Nephrol 28:748759. https://doi.org/10.1681/ASN.2016050576

71. Freel RW, Hatch M, Green M, Soleimani M (2006) Ileal oxalate absorption and urinary oxalate excretion are enhanced in Slc26a6 null mice. Am J Physiol Gastrointest Liver Physiol 290:G719-G728. https://doi.org/10.1152/ajpgi.00481.2005

72. Jiang Z, Asplin JR, Evan AP et al (2006) Calcium oxalate urolithiasis in mice lacking anion transporter Slc26a6. Nat Genet 38:474-478. https://doi.org/10.1038/ng1762

73. Clark JS, Vandorpe DH, Chernova MN et al (2008) Species differences in $\mathrm{Cl}-$ affinity and in electrogenicity of SLC26A6mediated oxalate/Cl- exchange correlate with the distinct human and mouse susceptibilities to nephrolithiasis. J Physiol 586:1291-1306. https://doi.org/10.1113/jphysiol.2007.143222

74. Worcester EM, Fellner SK, Nakagawa Y, Coe FL (1994) Effect of renal transplantation on serum oxalate and urinary oxalate excretion. Nephron 67:414-418. https://doi.org/10.1159/00018 8014

75. Pinheiro HS, Câmara NOS, Osaki KS et al (2005) Early presence of calcium oxalate deposition in kidney graft biopsies is associated with poor long-term graft survival. Am J Transplant 5:323-329. https://doi.org/10.1111/j.1600-6143.2004.00684.x

76. Truong LD, Yakupoglu U, Feig D et al (2004) Calcium oxalate deposition in renal allografts: morphologic spectrum and clinical implications. Am J Transplant 4:1338-1344. https://doi.org/10.1 111/j.1600-6143.2004.00511.x

77. Olsen S, Burdick JF, Keown PA et al (1989) Primary acute renal failure ("acute tubular necrosis") in the transplanted kidney: morphology and pathogenesis. Medicine (Baltimore) 68:173-187. https://doi.org/10.1097/00005792-198905000-00005

78. Memeo L, Pecorella I, Ciardi A et al (2001) Calcium oxalate microdeposition in failing kidney grafts. Transplant Proc 33:1262-1265. https://doi.org/10.1016/s0041-1345(00)02470-2

79. Bilgin N, Tirnaksiz MB, Moray G et al (1999) Early recurrence of oxalate deposition after renal transplantation in a patient with primary hyperoxaluria type I. Transplant Proc 31:3219-3220. https://doi.org/10.1016/s0041-1345(99)00699-5 
80. Riksen NP, Timmers HJLM, Assmann KJM, Huysmans FTM (2002) Renal graft failure due to type 1 primary hyperoxaluria. Neth J Med 60:407-410

81. Suneja M, Kumar AB (2013) Secondary oxalosis induced acute kidney injury in allograft kidneys. Clin Kidney J 6:84-86. https ://doi.org/10.1093/ckj/sfs167

82. Cuvelier C, Goffin E, Cosyns J-P et al (2002) Enteric hyperoxaluria: a hidden cause of early renal graft failure in two successive transplants: spontaneous late graft recovery. Am J Kidney Dis 40:6. https://doi.org/10.1053/ajkd.2002.33934

83. Rankin AC, Walsh SB, Summers SA et al (2008) Acute oxalate nephropathy causing late renal transplant dysfunction due to enteric hyperoxaluria. Am J Transplant 8:1755-1758. https://doi. org/10.1111/j.1600-6143.2008.02288.x

84. Parasuraman R, Zhang L et al (2011) Primary nonfunction of renal allograft secondary to acute oxalate nephropathy. Case Rep Transplant 2011:876906-876914. https://doi.org/10.1155/2011/876906

85. Lieske JC, Spargo BH, Toback FG (1992) Endocytosis of calcium oxalate crystals and proliferation of renal tubular epithelial cells in a patient with type 1 primary hyperoxaluria. JURO 148:15171519. https://doi.org/10.1016/s0022-5347(17)36954-9

86. Khan SR, Shevock PN, Hackett RL (1992) Acute hyperoxaluria, renal injury and calcium oxalate urolithiasis. JURO 147:226-230. https://doi.org/10.1016/s0022-5347(17)37202-6
87. de Water R, Boevé ER, van Miert PP et al (1996) Pathological and immunocytochemical changes in chronic calcium oxalate nephrolithiasis in the rat. Scanning Microsc 10:577-587 (discussion 587-90)

88. Umekawa T, Chegini N, Khan SR (2002) Oxalate ions and calcium oxalate crystals stimulate MCP-1 expression by renal epithelial cells. Kidney Int 61:105-112. https://doi.org/10.104 6/j.1523-1755.2002.00106.x

89. Schepers MSJ, van Ballegooijen ES, Bangma CH, Verkoelen CF (2005) Crystals cause acute necrotic cell death in renal proximal tubule cells, but not in collecting tubule cells. Kidney Int 68:1543-1553. https://doi.org/10.1111/j.1523-1755.2005.00566 .X

Publisher's Note Springer Nature remains neutral with regard to jurisdictional claims in published maps and institutional affiliations. 